\title{
Between Girls: Lateral Discipline in Henry Handel Richardson's The Getting of Wisdom.
}

\section{Hilary Emmett}

Towards the very end of Henry Handel Richardson's (Ethel Florence Lindesay Richardson's) 1910 novel The Getting of Wisdom, a character eschews the 'continual discipline' of the classroom as either student or teacher and declares her intention 'to be a writer.'1 Presented here as oppositions-the space of the school is one of regulation and correction where the life of the writer holds the promise of liberation-these two positions are far more intimately and tensely bound throughout the novel than this closing binary would suggest. Indeed, as the novel's plot traces the school days of its protagonist, Laura Rambotham, its form adopts (but quickly throws off) the constricting conventions of the sentimental school story. The complex intertextuality of Richardson's writing thus mirrors Laura's subjection to-and ultimate freedom from — the disapproving, disciplining gaze of her peers. In taking up motifs and plot points from domestic fictions and school stories only to reject them in favour of the Künstlerroman, Richardson also rejects the didactic role of sentimental literature itself. ${ }^{2}$

Through an exploration of the operations of the gaze in Richardson's text, I explore the ways in which girls' behaviour, and Laura's in particular, is regulated by forms of looking and seeing within the space of the Ladies' College. A focus on the gaze reveals

\footnotetext{
${ }^{1}$ Henry Handel Richardson, The Getting of Wisdom (1910; repr, Melbourne: Text Publishing, 2000), p. 254. All further parenthetical references are to this edition. 2 Joe Sutliffe Sanders offers a concise but thorough literature review of criticism describing the disciplinary efficacy of sentimental literature in Disciplining Girls: Understanding the Origins of the Classic Orphan Girl Story (Baltimore: Johns Hopkins University Press, 2011), pp. 1-2.
} 
where the ultimate authority for the management of behaviour in the school lay—far less in the figures of the teachers or principal than in those young women represented as Laura's peers. Try as she might, Laura can never see or be seen 'eye to eye' with her peers; her most egregious offences against the codes governing conduct are figured in the novel as, in turn, failures to see, or tendencies to see too much. And yet, her failure to be moulded by the eyes of her beholders is the saving grace that ultimately sees her ambitions fulfilled and horizons broadened, in contrast to those who live out conventional lives as wives and mothers or provincial governesses. The discipline to which Laura is subjected is ultimately ineffective.

Richardson's representation of what I call 'lateral discipline' in The Getting of Wisdom is significant for the way in which it makes visible the reorienting of disciplinary structures that took place as the private, domestic tuition of middle-class girls gave way to institutional, collective schooling in the last third of the nineteenth century. ${ }^{3}$ Focussing on the 1910 novel which fictionalizes her experience of Melbourne's Presbyterian Ladies' College from 1883-1887, this article considers her representation of girls as not just objects but as agents of disciplinary action. Reading this novel thus requires a reorientation of our own theoretical models for thinking about discipline, in particular, the Foucauldian panopticon and his conception of the segmented space of the school, which do not allow for the kinds of sideways glances that proliferate across Richardson's novel. The Getting of Wisdom provides an opportunity to historicize and theorize anew the role played by the peer group in shaping girls, a role that was a cause for both celebration and concern by ${ }^{3}$ See Shirley Foster and Judy Simons' What Katy Read for a reading of the ways Angela Brazil's 1917 Madcap of the School also registered this shift. Shirley Foster and Judy Simons, What Katy Read: Feminist Re-readings of 'Classic' Stories for Girls. (London: Macmillan, 1995), p. 193. 
commentators of the time. I argue that in boarding school novels such as Richardson's, discipline functions laterally, between peers, in ways that often reiterate the vertical authority of parents and teachers but also contest it, moving into the space created by its failures or absences. This representation of relations between girls has its closest analogue in very contemporary, 'postfeminist' accounts of 'relational aggression' within 'girl culture'; ${ }^{4}$ I draw on such accounts here to argue that this form of discipline-where girls' behaviour is shaped through the granting and withholding of friendship-has a much longer history than the last two decades of scholarship would suggest, including a history of critique in the form of texts like Richardson's. For all that Laura seeks identification with her fellow pupils, she continually side-steps the full force of their disciplinary actions; these 'swerves' disrupt the linear operations of socialization by teachers or peers. Laura's incorrigible 'willfulness,' to use Sara Ahmed's term, her ability to disrupt, in spite of herself, her own forward movement to social and academic success, and to womanhood, is thus not the failing that Laura feels it to be throughout her time at the College but is what enables her realization as a Modernist subject, with all the rich sense of interiority and selfawareness that such a designation entails. ${ }^{5}$

\section{The Getting of Wisdom: Context and Reception History}

\footnotetext{
${ }^{4}$ For a definition of 'indirect' or 'relational aggression' among girls as the 'use of relationships to hurt and psychologically injure those they are close to' and an account of the recent surge in feminist scholarship on the topic see Jessica Ringrose, Postfeminist Education? Girls and the Sexual Politics of Schooling (London: Routledge, 2013), pp. 28-31. ${ }^{5}$ Ahmed notes of the 'swerve' that the 'swerve is just enough not to travel straightly; not to stay on course. Oh the potential of this not!' (original emphasis). Sara Ahmed, Willful Subjects (Durham, North Carolina: Duke University Press, 2014), p. 9.
} 
The time of Ethel Florence Lindesay Richardson's attendance at Melbourne's Presbyterian Ladies' College (PLC) was one of rapid expansion in the education of Australian girls in terms of access, duration, and numbers in schooling. As Craig Campbell and Helen Proctor have observed, from the 1860s onward, '[g]irls as well as boys became more likely to receive a prolonged education [and] the school began to assume an historically unprecedented centrality in the lives of Australian young people.'6 Prolonged, compulsory schooling, they argue, was a new way to govern young women in danger of escaping the kinds of patriarchal authority, 'monarchic, aristocratic, [and] church,' that were seen to be breaking down at this time. ${ }^{7}$ The school, rather than the home, became the site on which girls learned the behaviours befitting a rising generation of citizens. The 'ladies' school' in nineteenth-century Australia was thus at first 'obliged to take as its institutional and psychological paradigm the mother and her daughters in the private sphere. The shaping of the female persona necessitated constant surveillance of all transactions within the school, and between the school and the outside world.'8 Richardson's biographer, Michael Ackland, noted the gruelling routine of her schooldays, remarking that through rigidly scheduled activities 'ongoing surveillance and reigning in of pubescent impulses were thereby assured. ${ }^{9}$ Yet in many ways, as a 'corporate' rather than 'ladies' school, PLC was able to shift this paradigm. ${ }^{10}$ Campbell and Proctor note that PLC (founded in 1875) was the first

\footnotetext{
${ }^{6}$ Craig Campbell and Helen Proctor, A History of Australian Schooling (Sydney: Allen and Unwin, 2014), p. 65.

${ }^{7}$ Campbell and Proctor, p. 82.

8 Marjorie Theobald, Knowing Women: Origins of Women's Education in Nineteenth-century Australia (Cambridge: Cambridge University Press, 1996), p. 51.

${ }^{9}$ Michael Ackland, Henry Handel Richardson: A Life (Cambridge UP, 2004), p. 62.

10 Theobald notes that 'PLC was corporate in the sense that it was created, owned and governed by the Presbyterian Church, although it was never lavishly endowed by
} 
'modern' school for girls in Australia, notable for its adoption of a curriculum modelled on that offered by English Public Schools for boys-including classical languages and mathematics - and for the fact that its students were entered for public examinations with a view to attendance at university. It did, however, also teach 'accomplishments' such as music and dance, promoting itself on the basis that it was producing 'ladies' rather than 'academic swats.'11 Marjorie Theobald describes the school's cultivation of an educational 'mystique': 'physically imposing, self-consciously pioneering and ambitious [PLC promoted] itself as an icon of female education in a way the ladies' academies and convent ladies' schools had never done.'12 Its move towards a more public-facing curriculum was signified by the appointment of a male principal, Charles Henry Pearson. A key figure in the liberalization of education in the then colony of Victoria and the first Principal of the College, he expounded on this ethos in 'The Higher Culture of Women,' his opening address to the college and its constituents. In the Australian colonies, he proposed, where even the men of the wealthy classes were largely 'uninstructed' in the knowledges befitting the sons of English gentlemen, it was particularly vital that the growth of a "body of uninstructed, desultory, wealthy women' be avoided. The 'elevation and refinement of young countries,'

church or private benefaction as were the denominational boys' schools of Melbourne. As [Joyce Senders] Pedersen argues, the hierarchical structure of church, council and principal shifted the locus of power in favour of the school and weakened the control which individual parents had wielded over the private proprietor of the ladies' academy.' 'The PLC Mystique: Reflections on the Reform of Female Education in Nineteenth-century Australia', Australian Historical Studies, 23 (1989), pp. 241-259 (p. 244). http://dx.doi.org/10.1080/10314618908595811 [accessed 30 July 2017]. ${ }^{11}$ Campbell and Proctor, p.91. We can hear in this opposition between 'ladies' and 'swats' an echo of the late eighteenth-century anxiety about the 'bluestocking.' As Marjorie Theobald notes, for much of the nineteenth century the 'accomplished woman's learning was deployed in the private sphere, enhancing her own womanly excellence, and serving others' where the 'bluestocking' was frequently reviled due to her unseemly and public aping of the male mind. Knowing Women, p. 22.

12 Theobald, 'PLC Mystique,' p. 244. 
such as Australia, depended on the education of middle-class women. ${ }^{13}$ In her study Empire Girls, a comparative analysis of Bildungsromane by white women writers from South Africa, Canada, and Australia, Mandy Treagus confirms that it is clear from the narrative of Wisdom that 'the school's purpose is at least in part an imperialist one.' She notes that the (fictional) PLC's curriculum emphasizes English over Australian history (resisted by Laura, who comes close to ignominious failure when her final History examination contains a question on Oliver Cromwell's foreign policy), while the hapless elocution teacher is reduced to histrionics in her attempts to produce the correct British accent in her pupils. ${ }^{14}$ As corporate models of elite private schooling developed in this period State and parental attitudes came to resemble those held by many the present day: the notion that a child's schooling was an 'investment' in their future. ${ }^{15}$ This attitude is certainly evident in Laura Rambotham's mother's reasons for sending Laura to the Ladies' College, though she regularly regrets her decision as Laura returns from the school during the holidays with a demonstrated disdain for her home town (p. 238). Thus, Richardson's novel registers that

${ }^{13}$ Charles Henry Pearson: Fellow of Oriel and Education Minister in Victoria: Memorials by Himself, his Wife and his Friends, ed. by William Stebbing (London, New York \& Bombay: Longmans, Green \& Co., 1900), p. 209.

$<$ https://archive.org/stream/charleshenrypear00pearrich/charleshenrypear00pearrich d jvu.txt $>$ [accessed 29 April 2017]. Narratives such as Pearson's bear out Theobald's revisionist account of the hitherto uncritically 'whiggish' narrative of the history of women's education as one of 'progress towards complete equality with men.' 'PLC Mystique' p. 241. Pearson's address demonstrates the strong correlations between even reformist supporters of women's education and proponents of 'Republican Motherhood' (to use the well-established term from U.S. history), who argued that women required an education in line with that offered to young men in order to be better mothers to citizensons. For the foundational account of this concept, see Linda Kerber, 'The Republican Mother: Women and the Enlightenment-An American Perspective,' American Quarterly 28.2 (1976), pp. 187-205.

${ }^{14}$ Mandy Treagus, Empire Girls: The Colonial Heroine Comes of Age (Adelaide: University of Adelaide Press, 2014), p. 210.

${ }^{15}$ Campbell and Proctor, p. 65. 
even as prolonged schooling (from primary into secondary education) was thought of as a positive social development, with increased opportunities for the State to 'regulate, supervise, moralize and even create more satisfactory populations,' anxieties also proliferated about the attendant influence of the peer group. ${ }^{16}$ In her analysis of the way Angela Brazil's prolific girls' school stories reflected changes in the structure and curriculum of girls' education at the turn of the twentieth century, Michelle Smith cites the 1907 book by influential British Headmistress, Sara Burstall, in which she cautions against girls in school having the same kind of moral influence over one another as that enjoyed by boys. While Burstall endorsed the 'introduction of games' to the regimen followed by schoolgirls as this evidence of 'the influence of girls on one another ... acting for good,' she shared the concern of 'some persons' that 'a real lowering of tone, and a loss of innate refinement' could occur 'if girls are left to influence one another too much.' She goes on:

This, however, does not happen with girls whose own standard is reasonably high. They help, not hinder, one another; and if the tone of the school is good, a less refined girl, be she rich or poor, gentle or simple, is soon made to conform to it. The girls themselves can do far more in this way than any mistress, however watchful; they are much more likely to take the duty of maintaining the tone of the school on themselves.'17

\footnotetext{
${ }^{16}$ Campbell and Proctor, p. 65.

${ }^{17}$ Sara Burstall, English High Schools for Girls: Their Aims, Organization and Management (London: Longmans Green \& Co, 1907), p. 176.
} 
Regulation of girls' schools, Smith concludes, 'was perceived as needing to differ insofar as girls must be 'contained' by adults, whereas boys were afforded greater freedoms in rehearsal for later life.'18 For Shirley Foster and Judy Simons, in their feminist rereading of 'Classic Stories for Girls,' this containment was precisely what enabled the production of the clearly defined, communal ethos that so appealed to contemporary readers of school stories. ${ }^{19}$

The Getting of Wisdom was published in this climate of increased interest in the perils and promises of schooling girls. And in keeping with this polarity, it met with decidedly mixed responses. In literary circles, it was hailed as 'the best of all contemporary school stories,' its heroine described by H. G. Wells as 'a most adorable little beast. ${ }^{20} \mathrm{~A}$ reviewer for the Daily Chronicle praised its realism and honesty, deeming it 'the first really fine piece of fiction which Australia has given us. ${ }^{21}$ However, it was this very same verisimilitude that led to a decidedly chillier reception among those moving in education circles. Clive Probyn and Bruce Steele reproduce several of the more hysterical (in all senses of the word) reviews by those involved in the education of girls in their 2001 edition of the novel, along with Richardson's wry comment in one of her letters that the book was

\footnotetext{
${ }^{18}$ Michelle Smith, “Girls! Girls Everywhere”: Angela Brazil's Edwardian School Stories' in Childhood in Edwardian Fiction, ed. by Adrienne E. Gavin and Andrew F. Humphries (Basingstoke: Palgrave Macmillan, 2008), pp. 143-158 (pp. 145-146),

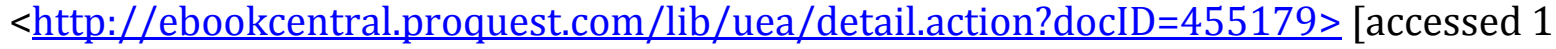
May 2017].

${ }^{19}$ Foster and Simons, p. 158.

${ }^{20}$ Clive Probyn and Bruce Steele. 'Introduction' to Academy Editions of Australian Literature The Getting of Wisdom (St Lucia: University of Queensland Press, 2001), pp. xxili. (p. xxxviii).

${ }^{21}$ Probyn and Steele, p. xl.
} 
'anathema' to school teachers. ${ }^{22}$ One such reviewer claims to have been a teacher in Melbourne:

I utterly deny that the thoughts and conversations of the ordinary Australian girl is [sic] such that would disgrace any respectable navvy. The book is coarse and sordid both in outlook and in expression, and is a libel on girlhood in general, and Australian girlhood in particular. ${ }^{23}$

While this intensity of feeling can be put down to the reviewer's desire to defend Australian girls and those who teach them from charges of vulgarity, it might also be due in part to disappointment that Richardson's novel did not adhere to the now well-established formula of the girls' school story.

\section{Henry Handel Richardson's Literary Interlocutors}

The Getting of Wisdom tells the story of Laura Tweedle Rambotham, a sensitive and imaginative (though also often obtuse and wilful) twelve-year-old, who is sent from her family's home in rural Victoria to school at Melbourne's most prestigious and established girls' school. Laura meets with repeated mishaps, culminating in her near failure of her final exams for matriculation (or university entrance). In no way an orthodox, inspiring tale of triumph over adversity, the overturning and ironization of key tropes of the school story (evident in its ironic title) demonstrates Richardson's rejection of the sentimental

22 Probyn and Steele, p. xxxviii. Closer to home, Ackland reports that one contemporary PLC teacher 'wanted 'to collect every copy \& burn them all.' 'A School of Authority: Richardson's Personal Investment in The Getting of Wisdom,' Southerly 59.2 (1999), pp. 17-30, (np).

${ }^{23}$ Probyn and Steele, p. xxxix. 
pedagogic novel in favour of an early Modernist 'portrait of the artist as a young woman.'24 Most significantly, the novel demonstrates Richardson's awareness of the literary and institutional operations of discipline, presenting her protagonist as both attracted to and repelled by the version of femininity that her peers seek to impose.

The anonymous review charging 'libel' against 'girlhood' was published in 1911, by which time the girls' school story was a well-established cultural phenomenon. So successful were such stories in the marketplace that the most popular authors of the genre published upwards of six titles a year. ${ }^{25}$ Perhaps unsurprisingly, given the rate at which such texts were produced, these stories tend to follow a particular formula. Describing the novels of L.T Meade, a pioneer of the genre, Beth Rodgers notes that this formula invariably entailed the integration of a new pupil whose actions precipitate a crisis in the school community, which must be resolved, in turn, by 'a moment of self-sacrifice and subsequent scene of public revelation.' In the vast majority of cases, the new girl is falsely accused of the action that ruptured the community in the first place-petty theft, cheating on some form of examination—and the recognition that she has been honourable all along is the occasion for the recommitment of all to the values of the school. Rodgers notes that in Meade's novels, the virtuous new girl is often paired with a 'wild girl' who must learn to put her wildness into the service of the school community before ultimately surrendering it

\footnotetext{
${ }^{24}$ For an account of the extent to which the events of the novel can be correlated to events in Richardson's own school career see Ackland, Henry Handel Richardson, pp. 67-74. 25 Beth Rodgers notes that L.T. Meade produced on average six full-length books a year. Beth Rodgers, “Enjoy the Last of your Schoolgirl Life": Making Transitions in the Girls' School Stories of L. T. Meade and Raymond Jacberns' in What Do We Tell the Children? Critical Essays on Children's Literature, ed. by Ciara Bhroin and Patricia Keenen (Newcastle Upon Tyne: Cambridge Scholars, 2012), pp. 163-181 (p. 168). Foster and Simons record that Brazil produced two full length novels and five short stories in the boarding school genre each year (p. 193).
} 
altogether. ${ }^{26}$ In the case of Annie Forest in Meade's foundational $A$ World of Girls: The Story of a School (1886), her ability to pass as a 'Gypsy,' along with her affinity for dogs, allows her to enact the heroic rescue of a younger child from kidnappers; such affinity for the uncivilized and the animal will surface again in Richardson's novel, but with alternative effects, as we will see.

The sentimental school story detailing the experiences of Australian girls was inaugurated by Margaret Parker (Macdonald). Her 1896 novel For the Sake of a Friend turns on a series of false accusations levelled at the virtuous orphaned heroine who attends Stormont House, 'the very grandest and most fashionable school in Melbourne' (16). ${ }^{27}$ Thought to be a sneak and a thief, Susannah (Susie) Snow suffers the disciplinary action of her peers who send her to Coventry and torment her in a variety of other creative ways until a near fatal accident elicits a confession from the true culprit. This novel has particular significance in the literary genealogy of pedagogical fictions that inform The Getting of Wisdom in that Macdonald was a contemporary of Richardson's at PLC. Margaret, along with her sister Isabel, founded the College's 'Magpie Club,' a literary society of which Richardson was (notably and noticeably) not a member. Richardson's biographer, Michael Ackland, writes that she was, in fact, refused entry; Isabel Macdonald is on the record as noting that her classmate was 'not invariably truthful.'28 The character of Mary Pidwall-

\footnotetext{
${ }^{26}$ Rodgers, pp. 169-70.

27 Margaret Parker, For the Sake of a Friend (1896; repr, London: Blackie and Son, 1912), p. 16.

${ }^{28}$ Quoted in Ackland, Henry Handel Richardson (p. 70). In Ackland's account, Macdonald was still 'smoking with indignation decades later' over Richardson's 'odious' behaviour while at PLC (p. 68); however, Probyn and Steele quote Macdonald as describing Richardson's tendency to embellish the truth rather more indulgently-'you couldn't believe a word she said, but all the same you couldn't help believing her yarns were true while she was telling them' (pp. xlviii-xlix). In a 1950 interview with the Melbourne Argus,
} 
known to all the girls simply by her initials, M. P.—an unimaginative and humourless young woman who takes it upon herself to educate Laura-is very likely a satirical portrait in which the Parker sisters are collapsed.

The instant and runaway success of Angela Brazil's The Fortunes of Philippa in 1906 cemented the place of the boarding school story in the British world. For all that Brazil overturned the sentimental conventions of the school story in her emphasis on the physical robustness of her heroines, her novels contained many of the hallmarks of Meade's formula, not the least of which was the transformation of the 'tropical blossom into an English rose.'29 In Australia, Constance Mackness took up Brazil's mantle in the 1920s, and authored several novels in which a 'madcap' character is reformed through the cultivation of a code of schoolgirl honour through participation in games, dramatic societies and other extra-curricular clubs. Almost all her novels entail an incident of false accusation and on resolution, the school re-establishes itself as a 'big, happy family. ${ }^{30}$ Her last novel, Clown of the School (1935) explicitly engages the influence of the peer group through the reformation of Mary Trevor whose pranks and impertinence frequently draw her friends into trouble. Mary is redeemed by the Headmistress's plan to turn her influence on her

Macdonald judiciously leaves out any commentary on Richardson's reputation as a fantasist, but she does remark decisively that her by then illustrious schoolfellow had not been a member of the Magpie Club. 'Her Schoolmates Became Famous' 30 September, 1950. http://trove.nla.gov.au/newspaper/article/22896872 [accessed 26 July, 2017]. ${ }^{29}$ Angela Brazil, The Fortunes of Philippa: A School Story (London: Blackie and Son, 1906), p. 208.

${ }^{30}$ Constance Mackness, The Glad School (Sydney: Cornstalk Publishing Company, 1927), quoted by Rachel Crawford, Bonza Schooldays: Online Bibliography and History of Australian School Stories, http://bonzaschooldays.blogspot.co.uk/2009/08/constance-mackness.html [accessed 31 July, 2017]. 
peers to good effect: introducing houses or 'guilds' to the school, Miss Maxwell redirects Mary's energies to the good of her guild. ${ }^{31}$

Equally, if not more significant than British school stories in defining the shape of 'novels about institutions' were sentimental pedagogical fictions hailing from the United States. ${ }^{32}$ The Getting of Wisdom opens with a scene of storytelling that could have been lifted directly from the pages of Louisa May Alcott's Little Women, or Susan Coolidge's What Katy Did, two of the most widely read novels for girls of the long nineteenth century. ${ }^{33}$ As Little Women opens with a reference to the sisters' Christmas play, a melodrama in which Meg will 'trail round in a white gown with [her] hair down, and wear gold-paper jewelry,'34 so The Getting of Wisdom begins with Laura Rambotham, or 'Wondrous Fair' as she has instructed her younger siblings to address her, weaving a tale of a prince's encounter with 'a beautiful lady, in a long white dress, that hung down to her ankles, with a golden belt and a golden crown' (p. 1). The comic contrast between the picture she creates of the princess's raiment and the reality of Laura's muddy boots and ill-fitting clothing is not lost on her

31 Constance Mackness, Clown of the School (London: Ward, Lock \& Co., 1935).

32 Probyn and Steele, p. xxxiv.

${ }^{33}$ Little Women is often read as the ur-text of modern literature for girls. Nina Baym, for example, notes that the novel marked the moment at which sentimental, domestic women's fiction was transformed into girls' fiction. Woman's Fiction: A Guide to Novels by and about Women in America 1820-1870 (Ithaca: Cornell University Press, 1978), p. 296. However, What Katy Did has enjoyed equally sustained popularity since its publication in 1872, particularly in Britain, Australia, and New Zealand-more so than in its native United States. By the late nineteenth century both novels were an entrenched feature of Australian girls' libraries. Ethel Turner was hailed by reviewers as 'Alcott's true successor' cited in Kerry White, “'True Blue Alcott": Lillian Turner's Reworking of Little Women and What Katy Did,' The Lu Rees Archives Notes, Books, and Authors, 4.9 (1987), p.2. Louise Mack's 1898 Girls Together, the second volume in her Teens trilogy, shows familiarity with the plot of Little Women, as one character holds the position familiar to generations of readers of Alcott's novel that 'Laurie [should] marry Jo, and the old Professor should die, or marry some kind fat lady in Germany.' (London: Pilgrim Press 1930), p. 181.

${ }^{34}$ Louisa May Alcott, Little Women (1868), Ch. 1, <http://www.gutenberg.org/files/514/514-h/514-h.htm> [accessed 1 May 2017] 
siblings. Nor is it lost on readers, who recognize from Alcott, Coolidge, and even L. M. Montgomery, the conventional discrepancy between the world of the imaginative heroine and what is presented as the prosaic reality of the world of the novel. It is a contrast designed to consolidate the truth of the authorial narrative by drawing attention to the obvious fictionalities which it contains. For Catherine Pratt, the presence of this fairy tale narrative at the outset of the novel signifies Richardson's critique of the ideological role played by the fairy tale in constructing late nineteenth-century womanhood and its drives towards love and marriage. ${ }^{35}$ Given the richness of Richardson's intertextual tapestry, this is certainly one thread in the fabric of the novel, but there are further distinct echoes here of the opening chapters of both Little Women and What Katy Did.

Laura's description of the princess's attire quickly moves into an account of Laura's own clothing, as Mrs Rambotham calls her into the house to fit her for her school dress. It is a moment that is doubly disagreeable to Laura: caught in between childhood and womanhood, Laura rebels both against the shortness of her dress, which will betray her lack of sophistication to her schoolmates, and against her mother's admonitions of how she must now 'learn to behave in a modest and womanly way.'36 Further echoes of Jo March resound in what is the first of many scenes in which Laura seeks to avoid any discussion of pending womanhood. Jo expostulates that

'I'm not [a young lady]! And if turning up my hair makes me one, I'll wear it in two tails till I'm twenty,' [...] pulling off her net, and shaking down a chestnut mane. I

35 Catherine Pratt, 'Gender Ideology and Narrative Form in the Novels of Henry Handel Richardson' (unpublished doctoral thesis, University of New South Wales, 1984), p, 268. 36 Richardson, p. 3 and p. 11; Pratt, p. 252. 
hate to think I've got to grow up, and be Miss March, and wear long gowns, and look as prim as a China Aster! ${ }^{37}$

By contrast, Laura escapes from this 'gendered maturity', imposed through clothes and her mother's advice, ${ }^{38}$ into a space significantly defined by its proximity to animals.

We learn here of Laura's love for all beasts, particularly those that are disabled or injured, or viewed as pests by adult members of the household:

Laura had given each of the chicks a name, and she now took Napoleon and Garibaldi up in her hand and laid her cheek against their downy breasts, the younger children following her movements in respectful silence. Between the bars of the rabbit hutch she thrust enough green-stuff to last the two little occupants for days; and everywhere she went she was accompanied by a legless magpie, which, in spite of its infirmity, hopped cheerily and quickly on its stumps. Laura had rescued it and reared it; it followed her like a dog; and she was only less devoted to it than she had been to a native bear which died under her hands. (p. 14)

Laura's affinity with the non-human harks back to the 'wild' girls of Meade's fiction and reproduces the figuration of both Jo March and Katy Carr-the sentimental heroines most in need of taming_in Alcott and Coolidge's texts. Jo 'was very tall, thin, and brown, and reminded one of a colt, for she never seemed to know what to do with her long limbs,

\footnotetext{
37 Alcott, Ch. 1.

38 Pratt, p. 252.
} 
which were very much in her way',39 whilst in Coolidge's novel, all the Carr children are described as belonging to some animal species or another; collectively, they 'roost' like chickens. Katy, like Jo, is 'the longest girl that was ever seen.' Known by all as the 'giraffe,' she resents the moniker as it reminds her of her growing body, 'all legs and elbows and angles and joints. ${ }^{\prime 40}$ These three girls—Laura, Jo, and Katy—are all instantiations of those who 'fail to do their gender right,'41 and who thus bear out Kathryn Bond Stockton's theorization of queer children and what she calls 'the interval of animal.'42 For Stockton, the family pet provides a figure of identification for such children that would halt their otherwise rapid progress towards adulthood; ${ }^{43}$ she suggests that, in Modernist women's writing in particular, 'animal/child bondings, especially for girls attracted to girls [provide] an outlet for feelings they long to express. [...] at turns a witness, confidante, rebel, protector, and pretend lover [...] the animal allows the girl to run a gamut of emotions [...] in the face of a future not careful of their pleasure. ${ }^{44}$ Resistant to growing up and being forced to perform set roles relating to gender and sexuality, queer children in literature grow sideways.

\footnotetext{
${ }^{39}$ Alcott, Ch. 1.

40 Susan Coolidge [Sarah Chauncey Woolsey], What Katy Did (1872; repr. New York: Dover, 2006), p. 18.

${ }^{41}$ Judith Butler, 'Performative Acts and Gender Constitution: An Essay in Phenomenology and Feminist Theory,' Theatre Journal 40.4 (1988), pp. 519-531, (p. 522). http://www.jstor.org/stable/3207893 [accessed 30 July, 2017].

${ }^{42}$ Kathryn Bond Stockton, 'Growing Sideways, or Versions of the Queer Child: The Ghost the Homosexual, the Freudian, the Innocent, the Interval of Animal', in Curiouser: On the Queerness of Children, ed. by Steven Bruhm and Natasha Hurley (Minneapolis: University of Minnesota Press, 2004), pp. 277-315.

${ }^{43}$ Stockton, 'Growing Sideways', pp. 280-281.

${ }^{44}$ Kathryn Bond Stockton, The Queer Child: or, Growing Sideways in the Twentieth Century (Durham \& London, Duke University Press, 2009), p. 53.
} 
In the passage just quoted, Laura is shown to have the affinity with animals that may be regarded as one of the hallmarks of the queer child; but it also manages to signal to us another marker of her queerness, which is gender transgression. The chicks (revealed shortly afterwards to be female by her mention of their future eggs) are named for the male military heroes so venerated by Romantic writers from Lord Byron (in the case of Napoleon) to Victor Hugo and George Sand (in the case of Garibaldi). Gender is a fluid and redefinable concept for Laura. Indeed, she explicitly seeks out transgressive play; her last tour of the family's garden takes in 'the tall fir-tree with the rung-like branches by which she had been accustomed to climb to the very tree-top; [and] the wilderness of bamboo and cane where she had been Crusoe.' Most tellingly, she lingers wistfully over 'the old fig tree with the rounded, polished boughs, from which, seated as in a cradle, she had played Juliet to Pin's Romeo, and vice versa — but oftenest Juliet: for though Laura greatly preferred to be the ardent lover at the foot, Pin was but a poor climber' (p. 13). While Laura's going away to school is less obviously a punishment for these queer behaviours than, for example, the exile of Judy in Ethel Turner's 1894 Seven Little Australians, we are told that, for better or worse - her own mother is ambivalent as to whether boarding school is the right place for her wilful daughter-the school will, in the words of Rambotham's maid, Sarah, 'knock all the nonsense out of 'er' (p. 18).

The maternal anxiety of Laura's mother about the necessity for discipline, and her own ability to perform it, is the first of many failures of vertical authority in the novel. When this failure is brought into relation with Richardson's repeated analogies between school and prison, the significance of peers as disciplinary agents is thrown into sharp relief. Richardson's use of the gaze and the mobilization of metaphors of the prison and the 
barracks throughout invite a turn to Foucault. Richardson's depiction of boarding-school

life looks not unlike a scenario already remarked upon by theorists of discipline and punishment—in this case, a kind of panopticism—but if we investigate the authority vested in peers to perform punitive action, we expose a mode of surveillance recognisable to contemporary analysts of 'girl culture' but which has in this very early phase of modern feminism itself avoided scrutiny and which now demands scholarly attention. The Getting of Wisdom returns a much longer history to these contemporary analyses, demonstrating that girls have surveilled and disciplined one another at least since the 'form' or peer group was instantiated by the move from domestic to corporate schooling. But where studies of contemporary girl culture are concerned on the one hand with the way in which the gaze helps construct and sustain the girl as social subject, and on the other with the ways in which the disciplining gaze damagingly colludes with patriarchy, Richardson recognises in the girls' sidelong glances the potential 'swerve' that will liberate her protagonist from the panoptic gaze. 45

45 Terri Apter and Ruthellen Josselson see the friend's gaze as the most significant source of girls' self-worth, the sign that 'she is special to someone outside her family.' Terri Apter and Ruthellen Josselson, Best Friends: The Pleasures and Perils of Girls and Women's Friendships (New York: Random House, 1999), pp. 3-4. Alison Winch provides a compelling account of what she calls the 'girlfriend gaze' in contemporary, 'postfeminist,' Western culture. This gaze is specifically to do with regulation of other women's bodies via what she terms a 'gynaeopticon,' an 'affective network of control,' such as an online 'thinspiration' forum, 'where the many girlfriends survey the many girlfriends.' Alison Winch, Girlfriends and Postfeminist Sisterhood (Basingstoke: Palgrave Macmillan, 2013), p. 10. Margaret E. Toye also discusses the 'female panopticon' as a signifier for 'female collusion in perpetuating patriarchy' in Angela Carter's second-wave feminist work. Margaret E. Toye. 'Eating Their Way Out of Patriarchy: Consuming the Female Panopticon in Angela Carter's Nights at the Circus' Women's Studies 36 (2007), pp. 477-506 (p. 481).

http://dx.doi.org/10.1080/00497870701593721 [accessed 27 July, 2017]. 


\section{'Lost to Sight': Subverting the Disciplinary Gaze}

Laura's first encounter with the College is heralded by her Cousin Grace's jibe that she's glad not to be the one destined to attend it, 'it looks just like a prison!' (p. 33). Indeed, aspects of the school are uncannily Foucauldian, not least the principal, Mr Strachey, whose authority is vested in his 'mere presence'; interestingly, it is 'the very unseeingness of his gaze [that] inspired awe' in the pupils (p. 88), he is an animate instantiation of the panoptic tower. Yet the narrative goes on to detail, with some insistence, the failures of the Principal and other authority figures to see. Even as the girls are watched by staff, the narrative exposes the governesses' blindspots when it comes to ensuring that their charges are seeing what they are supposed to, such as the game played by the older girls in identifying and sharing Bible verses containing sexual knowledge at which Laura soon excels (pp. 12122). These failures of sight are typically Foucauldian, in that the panopticon functions most effectively when there is no one doing the watching because discipline has been internalized. 46

Foucault's formulation evinces an investment in verticality, an orientation that assumes that discipline is centralized and comes from above. His description of the boarding school, for example, insists upon the partitioning of individuals. Discipline, he writes, proceeds from the distribution of individuals in space:

It does this first of all on the principle of elementary location or partitioning. Each individual has his own place; and each place its individual. Avoid distributions in groups; break up collective dispositions; analyse confused, massive or transient

46 Michel Foucault, Discipline and Punish: The Birth of the Prison (New York: Vintage, 1979), p. 201. 
pluralities. Disciplinary space tends to be divided into as many sections as there are bodies or elements to be distributed. ${ }^{47}$

The photographs that he provides, too, offer us representations of rigidly segmented space in which there is no possibility of lateral vision. Contrastingly, Laura is forever looking sideways, thereby dislodging her from her allocated position in this regimented space.

Laura's first encounter with her roommate, the formidable Lilith Gordon, entails just such a sideways glance, and its destabilizing misconstrual. Lilith receives a dressing down from Mrs Gurley for leaving an 'undergarment' carelessly flung across her bed:

Lilith Gordon neither fell on her knees nor sank through the floor. Her lashes were lowered, in a kind of dog-like submission, and her face was very red, when Laura ventured to look at her again; but that was all. And Mrs Gurley, having swept Jovelike from the room, this bold girl actually set her fingers to her nose and muttered: “Old brimstone Beast!" As she passed Laura, too, she put out her tongue and said: "Now then, goggle-eyes, what have you got to stare at!" Laura was deeply hurt. She had gazed at Lilith out of the purest sympathy. [...] She felt unspeakably far away, now, from the small, snug domain of home. (p. 41)

The novel's rapid move from domestic to institutional space highlights the burgeoning separation between the two domains in this period, but also signals the move away from

${ }^{47}$ Foucault, p. 143. 
the sentimental domestic fictions of the mid-nineteenth century that Richardson makes. In The Getting of Wisdom, the space of the school is other to the space of the domestic sphere, and its sentimental discipline is neither practiced by those in authority at the Ladies' College, nor, as Lilith's impertinence implies, would it necessarily be appreciated by its denizens. Whereas in Coolidge's Katy the hoydenish behaviour of schoolgirls results in their teacher's appeal to their better natures, her sorrow, disappointment and 'religious affliction' inducing tears of penitence, ${ }^{48}$ Lilith Gordon is humiliated but utterly unrepentant. Richardson's rendering here demonstrates clearly the link between these two positions and the defiance produced by heavy-handed discipline.

Another complex subversion of both top-down and lateral discipline occurs in a scene of public humiliation that occurs early on in Laura's tenure at the Ladies' College. Annie Johns, a day-scholar (in itself a déclassé position), is expelled for petty theft; at $\mathrm{Mr}$ Strachey's insistence, the expulsion takes place in front of the entire school. Liberated from their usual lessons, the students file in to witness the extraordinary event. Once the students are massed in the hall to the point of standing room only, the principal calls the unfortunate pupil to the stage. Richardson writes, 'Hundreds of eyes sought the unhappy culprit as she rose, then were cast down, and remained glued to the floor' (p. 113). What is intended as an exercise in public humiliation is resisted by the students: they refuse to participate in the girl's punishment. Laura is the only student to gaze frankly on the scene, less, it seems, out of obedience to the Principal than because of her sense of identification

${ }^{48}$ Coolidge, p. 22. A similar scene is enacted in Louise Mack's Teens in which the incorrigible Nell Neilly intercepts and eats the Headmistress's midday dinner. Impervious to all scolding, Nell dissolves into uncharacteristic tears 'when Miss Hammerton cast aside her sternness and her sarcasm, and spoke gently and sorrowfully.' Louise Mack, Teens: A Story of Australian Schoolgirls (1897; repr. London: The Pilgrim Press, 1930), p. 92. 
with the thief. This identification is not with Annie's actions-for all her frailties, Laura is not a thief-but with her poverty.

Laura's initial interest in Annie's punishment is quelled by a sideways glance from her neighbour, Tilly, who admonishes her sharply, 'you ARE a beast to stare like that' (p. 114). Tilly's admonition is not evidence that the students feel any kind of sympathy for the accused; on the contrary, it shows that there are punitive systems that take priority over directives issued from above. Gazing directly at a disgraced peer amounts to identification with her. Indeed, as the girls reflect on Annie's actions and the scene of her expulsion, Laura's desire to look at Annie, to see her as she suffered, is read as pity. As Laura herself reflects on her desire to absorb the scene in its entirety, the narrator suggests that what she felt was not pity but empathy: 'she had understood Annie Johns' motive better than anyone else' (p. 118). Recognizing that for her schoolmates 'the gap was not very wide between understanding and doing likewise,' Laura resiles from her own impulse to 'range herself on the side of the sinner; she longed to see eye to eye with her comrades' (p. 119, my emphasis). Collusion in this boarding school narrative is thus not a cosy affair of midnight feasts and pranks played on teachers, but a complex disciplinary apparatus geared towards the maintenance of elite and middle-class identities. And for most of the novel, it is conformity with such identities, tellingly figured in terms of the gaze-as 'seeing eye to eye' - to which Laura aspires, but at which she fails. Thus, the scene of Annie Johns' expulsion is a recurring nightmare, one in which 'stony faces, drooped lids, and stretched pointing fingers' are directed at her (p. 119).

Early scholars of girl culture, Terri Apter and Ruthellen Josselson, propose that the approving gaze lies at the heart of successful friendships between girls: 'as a girl or woman 
searches for what is genuine or authentic in herself, she looks in the mirror of her girlfriend's gaze. She hopes to find a confirming and comforting reflection. If she sees criticism or rejection, she can be struck with panic.' ${ }^{49}$ Similarly, Jessica Ringrose cites a recent American school board report which alerts parents and teachers to the fact that 'adolescent girls live in a world where best friends can become enemies overnight, where one look from another girl can mean the difference between isolation and belonging. It's a world where no one tells you why you can no longer sit at the lunch table with your friends. ${ }^{\prime 50}$ The turn-of-the-century boarding school equivalent of ostracism from the lunch table is, of course, to be sent to Coventry. Ironically, it is the desire to conform, to be like and to be liked by her peers, that is the occasion for Laura's extended sojourn there in The Getting of Wisdom. Her early academic success in the school results in her skipping a form, such that at the age of thirteen, she enters into classes populated with girls of sixteen and seventeen. For the most part, these girls are nearing the end of their schooling, but they are not the students destined to take the public examination with a view to attending university. Their interests largely lie in the mysteries of married life that await them soon enough, along with strategies for enlarging upon their limited experiences of sex and sexuality. The time they 'had still to spend at school was as purgatory before paradise' ( $\mathrm{p}$. 142). In a bid to gain their acceptance, Laura concocts a series of stories about an incipient love affair with the local Episcopalian curate. Her fantastical performance is exposed soon enough and her tales revealed as romantic fictions. Despite (indeed, equally because of) Laura's plea that she was simply fulfilling the appetite of her peers for such fantasies, she is ostracized.

\footnotetext{
${ }^{49}$ Apter and Josselson, Best Friends, p. 4.

${ }^{50}$ Ringrose, Postfeminist Education?, p. 35.
} 
The architect of Laura's punishment is the unsympathetic Mary Pidwall, a character of extreme and unimaginative rectitude (p. 199) who is known to her peers simply by her initials—a form of naming that reflects her exactness:

Such capers as the elder girl cut were only skin-deep; they were on the surface of her character, had no real roots in her: just as the pieces of music she played on the piano were accidents of the moment, without deeper significance. To Mary, life was already serious, full of duties. She knew just what she wanted, too, where she wanted to go and how to get there; her plans were cut and dried. She was very clever, very industrious, the head of several of her classes. Nor was she ever in conflict with the authorities: she moved among the rules of the school as carefully as an egg-dancer among his eggs. For the simple reason that temptations seemed to pass her by. (pp. 169-70)

M. P. is one of the 'leading spirits' of the College Literary Society and, despite having some literary talent, upholds truthfulness as the supreme value in all things, even at the expense of the creative exercise of the members' imaginations. Supremely judgemental about Laura's moral and literary failings, the crux of Richardson's satirical portrait comes as M. P. and her circle praise Laura's literary efforts for their truthfulness, despite the fact that 'not a word of her story was fact.' The wisdom Laura gleans from her time in the Literary Society boils down to this: 'as soon as you put pen to paper, provided you kept one foot planted on probability, you might lie as hard as you liked; indeed, the more vigorously you lied, the louder would be your hearer's applause' (p. 213). 
Laura Rambotham is the antithesis of the historical M. P.'s (Margaret Parker's) fictional heroine, Susie Snow. The latter falls foul of her peers due to her strict adherence to the rules of the exclusive 'Stormont House.' After refusing to post a letter to a disgraced former student on behalf of a fellow pupil, she is ostracized as a prig, this label soon snowballing into accusations of being a 'sneak' and finally a cheat, when an essay penned by her chief rival for academic success goes mysteriously astray. Susie Snow is, of course, guilty of none of the slurs cast upon her, and the decline into which she falls-exacerbated by a fall down a flight of stairs as the result of a prank-is the occasion for her stricken peers to recognize the ways in which they have wronged her. They abjectly seek her forgiveness. Laura, on the other hand, while no tell-tale, is guilty as charged on all other counts. She willingly participates in the illicit delivery of letters to boys, associates with uncouth and vulgar girls, and cheats in her final school examination by first claiming untruthfully not to have seen any of the questions on the exam paper and then by secreting a textbook in her bodice, which she proceeds to consult at an opportune moment. This episode differs from others like it in school stories in that Laura is not exposed, does not confess, and suffers no consequences. Amusingly, the only ill effect of her finding the opportunity to cheat is her loss of the religious fervour she had cultivated in the wake of the departure of the object of her intense crush, or 'pash,' Evelyn Souttar. Holding God accountable for creating the opportunity for her to cheat, Laura loses her faith in One who could snare her 'afresh into sin, and thus to prolong her dependence on Him' (p. 249).

If readers have held out for the formulaic ending of the re-establishment of the community around a reassertion of the values of the school, they will, like Richardson's anonymous reviewer, be sadly disappointed. By the novel's end, we see that this text has 
diverged irredeemably from the 'sentimental education' plot, and that all attempts by Laura herself, her comrades and her superiors to shape her into a figure of normative femininity have failed. Casting off her hat and gloves, she exits the building and runs into the December sunshine: 'fleet-footed as a spaniel' she races down 'the long straight path' until she comes to a sudden turn. Dashing around the bend, she 'is lost to sight,' and these are the last words of the novel (pp. 259-60). This rather explicitly queered ending to the novel—a dog-like girl veers off the straight and narrow and 'out of sight'—suggests that Laura's failures to see and be seen are, in fact, the source of her liberation from the restrictive versions of femininity, which the school sought to impose and to which her peers aspire. Neither marriage, like Evelyn Souttar, teaching, like M. P., or journalism, like the more sympatico 'Cupid,' holds any appeal for her. Laura, tellingly, wants 'to see thingsyes, that most of all. Hundreds and thousands of things. People, and places, and what they eat, and how they dress, and China, and Japan ... just tons' (my emphasis, original ellipses, 255). Equally telling, is that Richardson, both in Laura's voice and in that of the (arguably) more dispassionate narrator, reserves particular disdain for the vocation of teaching, revenging herself on the historical Isabel Macdonald by thwarting M. P.'s aspirations to 'have a school of [her] own some day' (254). There is understated but unmistakeable maliciousness in her final appearance in the novel: 'Within six months of leaving school, M. P. married and settled down in her native township; and thereafter she was forced to adjust the rate of her progress to the steps of halting little feet. Cupid went a-governessing, and spent the best years of her life in the obscurity of the bush' (256).

Richardson's novel thus offers us a version of discipline between girls that contests authority imposed from above, while leaving open the possibility that the lateral discipline 
operating in the space created by the disintegration of vertical influences may also be resisted. Equally, she situates her novel in opposition to the influential fictions of sentimental education emanating from the pens of writers such as Alcott, Coolidge, Meade and Parker. In revisiting and rejecting the pedagogy espoused by these novels and transforming their conventions into the Modernist Künstlerroman, Richardson also signals her own move away from the use of literature as itself an agent of discipline.

University of East Anglia.

\section{Acknowledgements}

Many thanks to Leigh Dale, Rachael McLennan, Nathan Garvey, and Katherine Baxter for their advice and commentary on earlier versions of this essay. 